\title{
Assessment of the Prospects of Application of Sewage Sludge from Lviv Wastewater Treatment Plants for the Purpose of Conducting the Biological Reclamation
}

\author{
Dmytro Vankovych', Oleh Bota ${ }^{2}$ Myroslav Malovanyy ${ }^{3}$, Mykola Odusha', \\ Ivan Tymchuk ${ }^{3}$, Iryna Sachnyk², Oksana Shkvirko ${ }^{3}$, Vasyl Garasymchuk ${ }^{2}$ \\ 1 Lviv City Utility Company “Lvivvodokanal", 64, Zelena Str., Lviv, 79017, Ukraine \\ 2 Center LTD Consulting, 1a/12, Lazarenka Str., Lviv, 79026, Ukraine \\ ${ }^{3}$ Lviv Polytechnic National University, Department of Ecology and Sustainable Environmental Management, \\ 12, S. Bandery Str., Lviv, 79013, Ukraine \\ * Corresponding author's e-mail: i.s.tymchuk@gmail.com
}

\begin{abstract}
The prospects of using the sewage sludge from Lviv wastewater treatment plants for biological reclamation was assessed. On the basis of the results of the monitoring of the qualitative and quantitative composition of sewage sludge accumulated in silt fields, the dependences of the distribution of sanitary-microbiological and ecologicalchemical characteristics of the accumulated sludge were investigated. Agroecological laboratory studies on estimating the possibility of using sewage sludge in a mix with natural sorbents as a substrate for cultivation of plants was carried out.
\end{abstract}

Keywords: sewage sludge, monitoring, agroecological research, heavy metals, silt field.

\section{INTRODUCTION}

Today, one of the global environmental problems of society, without the solution of which further development is impossible in general, is the uncontrolled generation and accumulation of waste. Accumulating in places of special and unauthorized storage, these wastes have a negative impact not only on the environment (the possibility of fires, greenhouse gases emissions, soil and groundwater pollution by heavy metals and other hazardous substances), but also on the human health. One of the types of hazardous waste is the organ-containing waste. Therefore, in recent decades, scientists in many countries around the world have been paying attention to the possibility of reusing the waste that contains an organic component. Such wastes include the waste from coal mining, sewage sludge (SS), the organic component of solid waste, and the waste from biogas production (spent biomass). Among the listed wastes, special attention is paid to the possibilities of reusing sewage sludge, which is formed after the stage of biological wastewater treatment (Malovanyy et al., 2016, Malovanyy et al., 2019).

In developed countries, sewage sludge has long been used successfully in various industries: as a fertilizer in agriculture, as a component of nutrient mixtures for reclamation of quarries and landfills, for the production of building materials, for biofuels and electricity and for the allocation of valuable components (nitrogen, phosphorus, etc.).

It is known that sewage sludge contains heavy metals and pathogenic microorganisms, which in the case of their use in agriculture can adversely affect the environment. Therefore, in the European Union, the use of sewage sludge in agriculture is regulated by Directive 86/278/EEC, which sets the maximum permissible concentrations of the heavy metals contained in SS. In addition, this Directive aims to promote the safe use of sewage sludge in agriculture in the EU in such a way as 
to prevent the adverse effects on soil, vegetation, animals and humans, as well as surface water and groundwater. The use of SS in agriculture is the most common method of disposal in Portugal, Ireland, Great Britain and Spain, where more than $70 \%$ of sludge is used compared to other methods (Kacprzak et al., 2017, Mininni et al., 2015, Inglezakis et al., 2014, Fijalkowski et al., 2017).

In the countries where the law prohibits or restricts the use of SS in agriculture, it are most often burned. This method of disposal is most common in Germany, the Netherlands and Switzerland (Eurostat, 2017, Pavšič et al., 2014).

In the countries such as Serbia and Malta, the traditional way of disposing of sewage sludge is to store it on sludge sites (Eurostat, 2017). In Sweden, Finland and the United Kingdom, sewage sludge has been used for several years for reclamation of disturbed lands. According to (Krüger \& Adam, 2015, Di Bonito, 2008), in the case of using a mixture of SS and lime, there are positive changes in the biological reclamation of landfills and spent quarries for coal mining. In Luxembourg, wastewater sludge is granulated and then exported to other countries for further incineration or composting (Fytili \& Zabaniotou, 2008). In Poland, SS is incinerated together with brown coal, wood or household waste to generate heat and energy (Twardowska et al., 2014).

The practice of recovering phosphorus from sewage sludge has become important in some countries of the European Union. For example, the Netherlands is one of the first countries in the world to implement full-scale recovery of phosphorus at Geestmerambacht municipal wastewater treatment plants. The country's task is also to replace $20 \%$ of the consumption of phosphorite ores (from which phosphorus is most often obtained) with the phosphorus reduced from SS. In addition, approximately $32 \%$ of the sewage sludge generated in the Netherlands is now used in the cement industry and power plants (Werle, 2015).

In the United States, since the early 1980s, composting of SS has been widely used in conjunction with solid waste to produce biogas. By applying the technology of anaerobic decomposition of sewage sludge, the electrical and mechanical energy is obtained, as well as heat, which is generated due to the formation of methane, which can be used with Hybrid energy storage systems (Shchur \& Biletskyi, 2019). Incineration is also a common way to dispose of sewage sludge in the United States. In Georgia, the ash from burning
SS is used to make bricks, in Minnesota - as an additive to asphalt mixtures, in Maryland - dried sewage sludge is used as fuel in cement kilns, etc. (Werle, 2015, Guedes et al., 2014).

In Japan, unlike in other countries, incineration is most often used to dispose of sewage sludge. In addition, other thermal processes of sludge disposal are also used, such as gasification, drying and carbonization. The products formed as a result of thermal processes are used for the production of building materials and phosphorus recovery, due to which a high rate of SS processing is achieved, with minimization of its disposal under the scenario of "zero sludge" (Christodoulou \& Stamatelatou, 2016).

A common practice in Japan is the phosphorus recovery from sewage sludge, using the crystallization process. As a result of this process, according to (Tyagi \& Lo, 2013), the final products are calcium phosphate and magnesium ammonium phosphate $\left(\mathrm{NH}_{4} \mathrm{MgPO}_{4} \cdot 6 \mathrm{H}_{2} \mathrm{O}\right.$ - struvite), which is an excellent fertilizer for plants due to its slow release property. The methods for determining the influence of the nature of the carrier on the physicochemical characteristics and catalytic properties can be implemented for the chemical processes of phosphorus removal (Nebesnyi et al., 2020).

In China, about $45 \%$ of all sludge is used in agriculture, $34.4 \%$ is stored on sludge sites and $3.5 \%$ is incinerated (Xu et al., 2014, Chen et al., 2012). Thickening, conditioning, dewatering and anaerobic digestion are used for pre-treatment of sewage sludge in China. Disposal of wastewater in China is mainly carried out according to the scheme "thickening - anaerobic digestion - dewatering - land application" (Yang et al, 2015).

In recent years, sewage sludge has been used to produce biogas and electricity at Chinese wastewater treatment plants. Ash, which is formed during the combustion of sewage sludge, is successfully used for the production of cement, bricks and other building materials.

Compared to other countries in the world, the situation with the disposal of sewage sludge in Ukraine is negative. The low level of sewage sludge utilization in Ukraine is mainly due to imperfect legislation and outdated treatment plant equipment. Therefore, at present the priority is the reconstruction of the treatment facilities with the possibility of obtaining ash from sewage sludge or biogas production.

Thus, in Kyiv at the Bortnytsia aeration station it is planned to build Block №1 and reconstruct 
Blocks № 2 and 3, which provide biological wastewater treatment with the creation of nitrification and denitrification zones in aeration tanks, as well as construction of gravity and mechanical sludge compactors.. As a result of such reconstruction of the treatment facilities, the final product of wastewater treatment will be ash, which can be used in industry (Kievvodokanal, 2018).

The construction of a biogas plant is planned at the wastewater treatment plants in Lviv. According to (Lvivvodokanal, 2018, Kizyeyev et al, 2016), the process of digestion in methane tanks of sludge from primary sedimentation and excess activated sludge from aeration tanks will be carried out at this plant. As a result of this process will be created biogas that can be used to produce electricity and heat.

Today in Ukraine, from 3 to $5 \%$ of sewage sludge is used in agriculture, which is regulated by DSTU 7359: 2013 "Waste water. Requirements for wastewater and its sediments for irrigation and fertilization". Thus, according to (Petruk et al., 2013) in the case of using the fertilizers based on sewage sludge in the amount of $500-600 \mathrm{~kg} / \mathrm{ha}$, there is an increase in yields of oats and potatoes by an average of $20 \%$, corn by $33.5 \%$, rapeseed $-24 \%$ etc.

In this study, the prospects for the use of accumulated sewage sludge in the silt fields of Lviv wastewater treatment plants were assessed. In the future, it would be appropriate to conduct a series of microbiological studies (Moroz et al, 2020).

The purpose of the study was to assess the prospects for the use of sewage sludge in Lviv wastewater treatment plants for biological reclamation. In order to do this, the volume and composition of accumulated sewage sludge were monitored, and the possibility of using them as part of the substrate for biological reclamation was assessed.

\section{MATERIALS AND METHODS OF RESEARCH}

A tachyometric survey for topographic and geodetic works for the purpose of binding and contouring of the silt field of Lviv wastewater treatment plants was performed by means of SOKKIA electronic tacheometer, which allows registering numerical and textual information, and performing coding of terrain objects in the field, which after appropriate processing of materials with the help of software and technology complexes such as "Topograd" and "DIGITALS", enable to automatically obtain the topographic plans in digital and graphical forms. Special milestones for distance reflectors were used in the work with the total station. The angles were measured in one complete step. The fluctuations of the values obtained from the half-receptions in the process of measuring the angle did not exceed $20^{\circ}$.

In the process of measuring the lines, the relative linear error did not exceed $1 / 2000$, provided that the absolute linear errors did not exceed $0.05 \mathrm{~m}$. The distance from the points of tacheometric courses (survey stations) to the pickets and the distance between the pickets did not exceed $500 \mathrm{~m}$.

The distances measured at the station to the picket points were registered in the electronic total station data terminal. At the same time, an outline was drawn in the process of surveying at each station. The outlines were decorated with symbols (with explanatory inscriptions), approximately following the scale of the survey, on separate sheets for each station, which are oriented along the course and on which they show the direction of orientation. The outlines showed the situation of the area and the boundaries of this land plot.

Execution of field works during the tacheometric survey was combined with preliminary inhouse processing of survey materials. In this case, the following were carried out:

- check of field logs and drawing up of the detailed scheme of a shooting basis;

- calculation of coordinates of survey stations;

- calculation of heights of all pickets at stations;

- overlapping points of the shooting base and the situation.

Processing of measurement results included:

- creation of cartographic material for the survey of the silt field at the address: Lysynychi village council, Pustomyty district, Lviv region;

- use of the Ashtech Solutitson program to calculate vectors - bases between points;

- assessment of the quality of measurements was performed on the absolute root mean square errors of location, the accuracy of which is in the range of $0.05-0.20 \mathrm{~m}$;

- Office processing of field data was performed on a personal computer using the "DIGITALS", "INVENTGRAD" and "MAPINFO" software. 
As a result of the work, a digital model and database were created in the form of a dmf-file.

The sampling of the accumulated sediments was performed using a metal cylindrical tube, such as a chute, with a bottom valve. The diameter of the sampler was $128 \mathrm{~mm}$, length $1 \mathrm{~m}$. A pipe was screwed to the top of the sampler, the length of which was increased by means of couplings.

The quality of the growth substrate was determined by a generally accepted method (DSTU ISO 2004, DSTU ISO 2005). In this method, plants are preferred to establish the possibility of using a growth substrate because they characterize the state of the environment in which they grow, multiply rapidly, react differently to harmful factors and thus allow choosing the most appropriate response for a particular study. The use of such method makes it possible to determine the combined biological activity of the influence of physicochemical factors on the environment (Horova \& Kulyna, 2008). The method is suitable for all types of soils, soil-forming materials, precipitated waste or chemicals that may be introduced into the soil. According to the method, the growing substrates are the studied mixture of soil and control soil, which is known to be of good quality.

Two types of plants belonging to one of the categories were selected for the experiment. Category 1 - monocotyledonous plants: rye, ryegrass, rice, oats, wheat, barley, sorghum, corn. Category 2 -dicotyledons: white mustard, canola, radish and wild turnip, Chinese cabbage, watercress, tomato, bean. Before using the seeds of each crop, an analysis was performed and the energy of their germination was determined. In each of the vessels, 10 identical seeds of the selected species were planted. For each replicate in each embodiment, the percentage of seed germination relative to the average germination in the control vessels was calculated. The length of the longest roots of each plant was measured and the average length of the longest root for each investigated growth substrate was determined. A statistical analysis was used to determine the smallest significant discrepancies between controls and test concentrations. For the study, in accordance with this method, different types of substrate based on soil, sewage sludge and natural sorbents were used, which were compared to the control soil.

\section{RESULTS AND DISCUSSION}

On the basis of the results of topographic and geodetic surveying, a map of the silt field morphology (Fig. 1) and its three-dimensional model (Fig. 2) were constructed, which clearly shows a decrease in the absolute marks of the silt surface in the eastern and northeastern directions from almost $247 \mathrm{~m}$ to slightly more than $244 \mathrm{~m}$. The elevation between the highest and lowest points reaches about $3 \mathrm{~m}$.

As can be seen from Figure 2, the surface of the silt field is uneven. This may be due to the fact that during the storage of sludge in the silt field, they were discharged on one side only, resulting in such an uneven distribution. The volume of sludge accumulated in the silt field was determined by multiplying the area of the silt field $\left(129006 \mathrm{~m}^{2}\right)$ by the sludge capacity $(3.16 \mathrm{~m})$. As a result of calculations, the volume of sediments in the silt field is $407659 \mathrm{~m}^{3}$.

In the course of research, the sanitary-microbiological characteristics of the accumulated sediments were determined. According to the research results, the sewage sludge accumulated in the silt field does not contain pathogenic microorganisms, and therefore can potentially be used as fertilizer for growing plants.

The ecological and chemical characteristics of the accumulated sediments were also determined. The research data show that the amount of moisture in the selected sediment samples is in the range of $6.45-15.23$ wt.\% (\% of total weight). The content of organic matter in sewage sludge is in the range of $28-44 \mathrm{wt} . \%$ The total mineral content in the sediments of the studied silt field is $46-60 \mathrm{wt} . \%$. The $\mathrm{pH}$ of the test medium is slightly alkaline in nature and ranges from 7.12 to 7.98 .

As for organic matter, in most wells there is a clear pattern of its reduction with the depth of sampling. Since the amount of organic matter in the near-surface layer of the silt field $(0-0.2 \mathrm{~m})$ is $35-44 \mathrm{wt} . \%$, and its maximum values in the lateral plan extend a wide strip from places of dumping of sediments in the northwest direction (Fig. 3).

In the middle interval of the silt field (1.4$1.6 \mathrm{~m}$ ) the organic matter content is in the range of 32-42 wt.\%. Laterally, the enrichment of sediments with organic matter coincides with the upper interval of the silt field. In the bottom interval $(2.8-3 \mathrm{~m})$, the organic content is the lowest and 


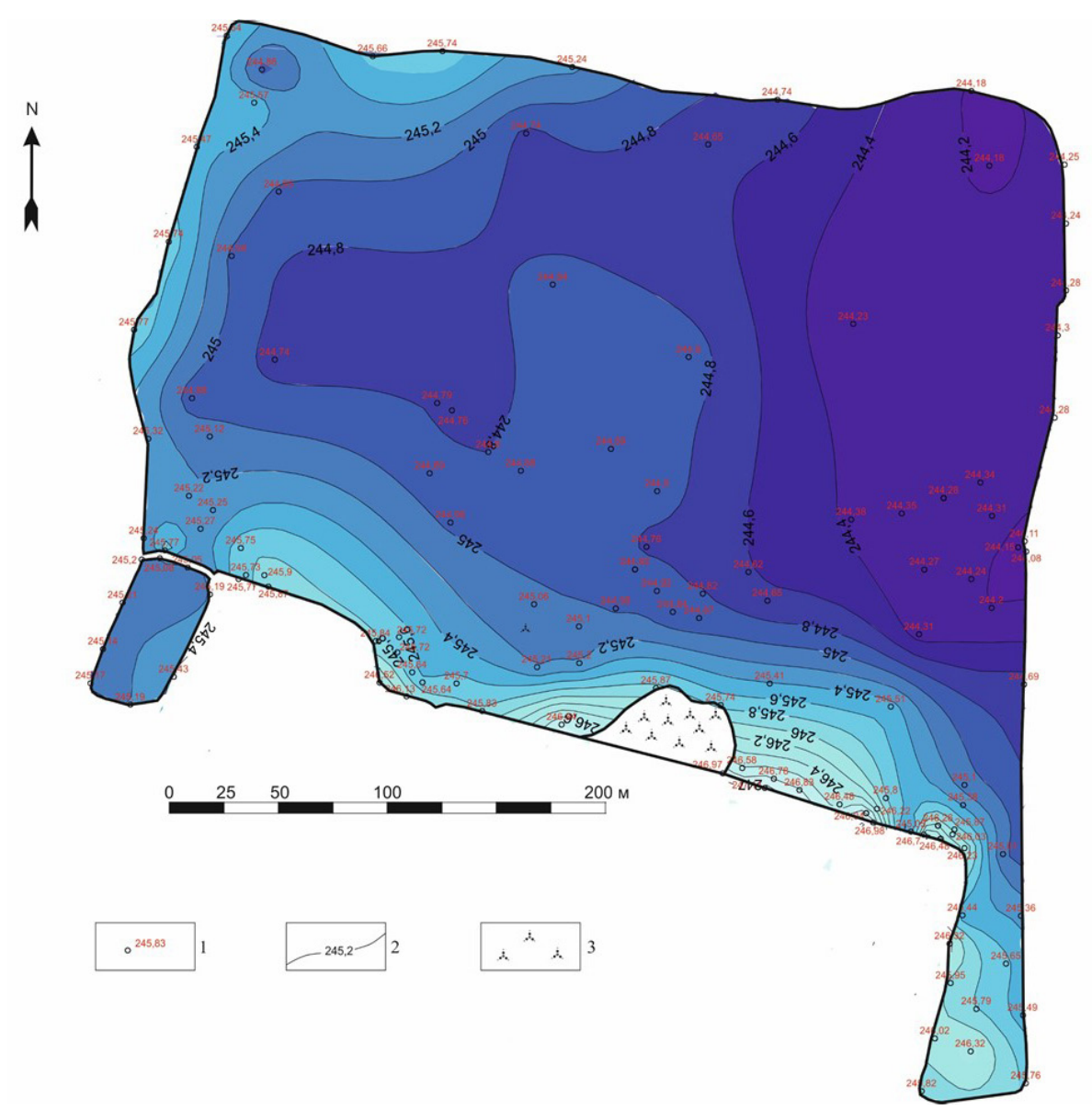

Fig. 1. Map of morphology of the silt field surface: 1 - geodetic point of measurement with data of absolute height, m; 2 - isogypsum; 3 - shrubs

amounts to $28-40 \mathrm{wt} . \%$. In comparison with the upper layers, the lowest content of organic matter is observed here in the central part, and its maximum values are observed in the peripheral parts of the silt field.

Heavy metals (Malovanyy et al., 2020) and petroleum products (Zelenko et al., 2019) can be sorbed in activated sludge, natural zeolites, bentonites and other types of natural sorbents. The content of mobile forms of metals in the accumulated sewage sludge was determined. The content and nature of the distribution in the body of the accumulated sludge of such metals as $\mathrm{Cu}, \mathrm{Pb}, \mathrm{Ni}, \mathrm{Cd}, \mathrm{Zn}, \mathrm{Cr}, \mathrm{Co}, \mathrm{Mn}, \mathrm{Fe}$ were established. According to the results of monitoring studies, it was found that both the concentrations of mobile and gross forms of heavy metals in the sludge field sediments do not exceed the MPC. The Mn content in the depth range of 2.8-3.0 m is shown in Figure 4.

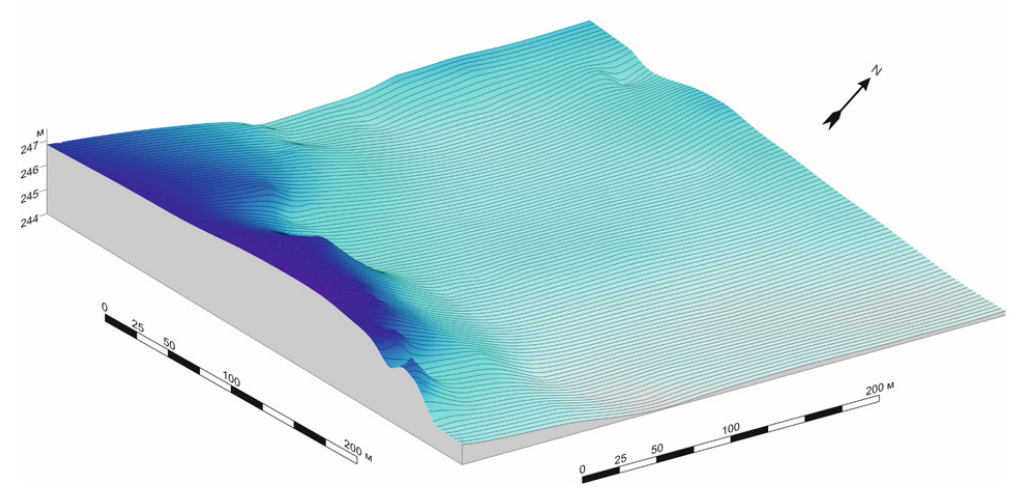

Fig. 2. Three-dimensional model of silt field surface morphology (without lower silt field protrusions) 


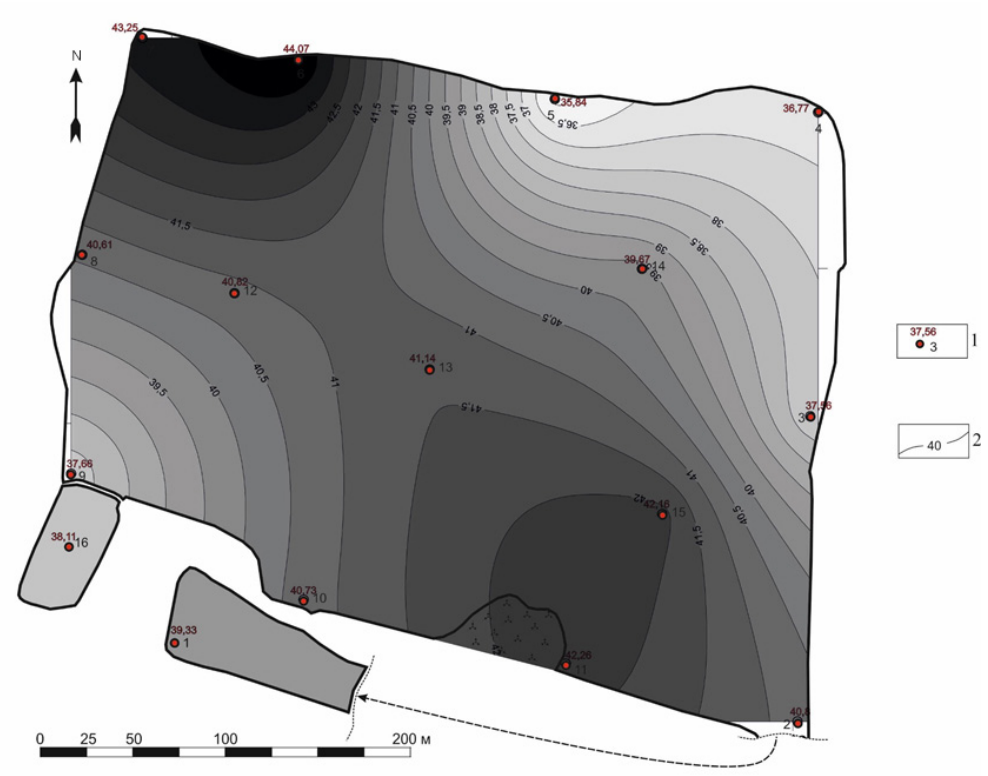

Fig. 3. Map-scheme of organic matter content in the depth range 0-0.2 m: $1-$ number of wells and organic matter content, wt.\%; 2 - isolines of the same content of organic matter

In order to determine the potential ability to use the accumulated sewage sludge as a fertilizer in agriculture and in the process of biological reclamation of disturbed lands, the content of individual nutrients was analyzed: total nitrogen $\left(\mathrm{N}_{\text {total }}\right)$, ammonium nitrogen $\left(\mathrm{NH}^{+}\right)$and phosphorus (mobile form in terms of $\mathrm{P}_{2} \mathrm{O}_{5}$ ). Studies have shown that the content of total nitrogen in the sewage sludge from the Lviv wastewater treatment plant ranges from 2.1 to $3.5 \%$ wt., which meets the standards of DSTU 7369: 2013 for their use in agriculture. In the vertical distribution of total nitrogen in most wells, there is an increase in its amount with depth. The content of ammonium nitrogen in the selected samples of accumulated sewage sludge varies between $318-892 \mathrm{mg} / \mathrm{kg}$ of sludge. There are no regularities in the vertical distribution. The content of mobile form of phosphorus (in terms of $\mathrm{P}_{2} \mathrm{O}_{5}$ ) in sludge is $1431-2160 \mathrm{mg} / \mathrm{kg}$ of air-dry matter. As for the vertical distribution, no patterns can be traced. Its largest values are found in the section

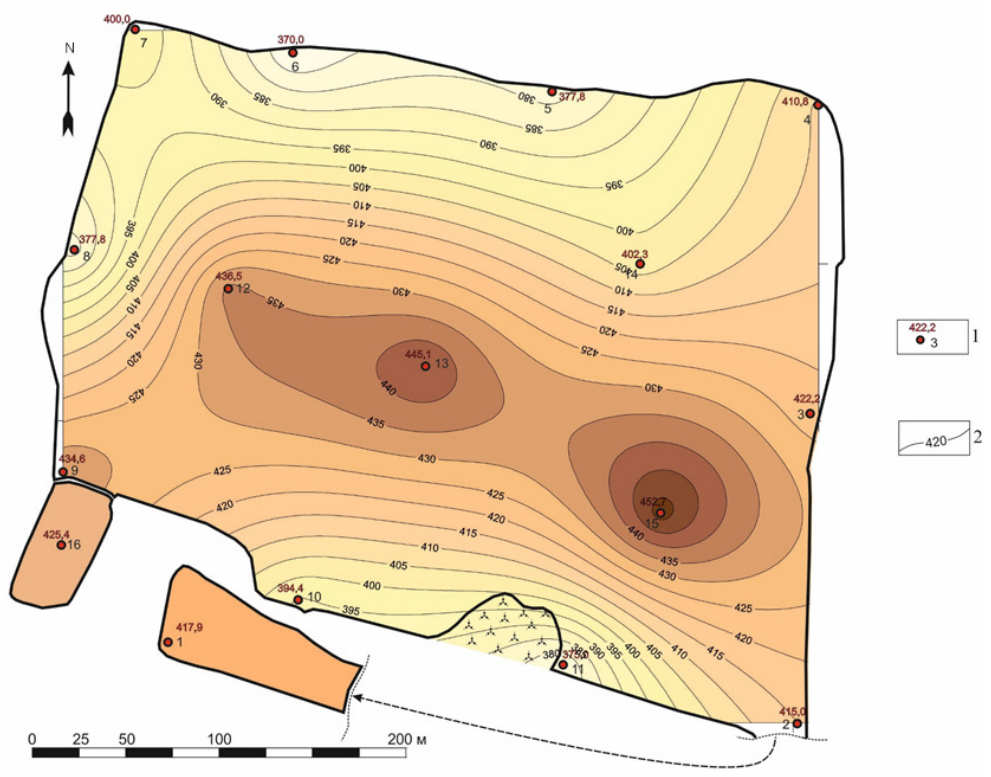

Fig. 4. Schematic map of Mn content in the depth range 2.8-3.0 m: 1 - well number and $\mathrm{Mn}$ content, $\mathrm{mg} / \mathrm{kg} ; 2$ - isolines of the same content of Mn 
of the well №13, which is located in the central part of the silt field.

Agroecological studies are important for determining the suitability of substances, including the use of sewage sludge in agroecology (Tymchuk et al., 2020). Agroecological laboratory studies to assess the possibility of using sewage sludge as a substrate for growing plants were performed with dark gray podzolic soil, to which sewage sludge was added in the ratio (\%): 100:0; 80:20; 60:40; 40:60; 20:80; 0:100. The created substrate was placed in Petri dishes and 10 seeds of common barley (Hordeum vulgare), white mustard (Sinapis alba) and watercress (Lepidium sativum) were planted in it. For the reliability of the studies, the experiments were performed in quadruplicate. During the experiment, observations were made on such indicators as: time of emergence of sprouts, their number per day, total germination.

According to the results of research, it was found that even a small proportion of sewage sludge (20\%) in the substrate, with this type of storage has a very negative effect on the germination of all plant species. In the samples with a sediment content of more than $40 \%$, the development of dangerous fungi and mold was observed.

At the next stage of research, dark sediments were added to the dark gray podzole soil in the amount (\%): $0 ; 20 ; 25 ; 30 ; 35 ; 40$. In the same substrate in the amount (\%): $0 ; 5 ; 7.5 ; 10$ added natural zeolite. For the reliability of the data, the experiments were performed in triplicate. Bioindication was performed in Petri dishes by planting on the created substrate 10 seeds of barley (germination 95-97\%). During the experiment, the following indicators were observed: time of emergence of sprouts, their number per day, total germination. Upon completion of the study, the length and weight of the aboveground part and roots were measured.

It was established that the use of substrate based on sediments and zeolite has a positive effect on plant growth and development. Thus, the average height of the terrestrial part of plants (stems) in almost all samples is greater than in the control sample (Fig. 5).

As can be seen from Figure 5, in the substrate with sewage sludge content of $35 \%$ and zeolite content of $0 \%$, the average height of the terrestrial part of plants exceeds the control indicator by $24,4 \%$, but in the substrate with sewage sludge content of $40 \%$ this indicator is lower by $18,4 \%$.
In the samples with a zeolite content of $5 \%$ and a sewage sludge content in the substrate of $40 \%$, the average height of the ground part exceeds the control indicator by $20.2 \%$, and in the sample with a sewage sludge content of $20 \%$ it is lower by only $1.09 \%$. In the substrate with a zeolite content of $7.5 \%$ in all samples, there is an increase in the average height of the aboveground part of the plant compared to the control by $31.8 \%$. In the samples with a sorbent content of $10 \%$, the average height of the ground part in comparison with the control sample is higher by $27.8 \%$ in the substrate with sewage sludge content of $30 \%$ and lower by $2.4 \%$ - with the sewage sludge content of $25 \%$. Thus, the best growth rate of the terrestrial part of the plant is observed in the substrate with a sewage sludge content of $35 \%$ and a zeolite content of $7.5 \%$.

At the next stage, the study was performed with two types of substrate: in the first added dark gray podzole soil, sewage sludge and zeolite, in the second - dark gray podzolic soil, sewage sludge and glauconite in the ratio (\%): 50:40:10. Comparisons were performed with the control sample (soil). Bioindication was performed in plastic cups (volume $500 \mathrm{ml}$ ) by planting 10 seeds of barley (germination 95-97\%) and 30 seeds of ryegrass (germination 90-93\%). In order to ensure the reliability of the data, the experiments were performed in triplicate. The general appearance of plants on the $40^{\text {th }}$ day is shown in Figure 6.

It was found that in the control samples, the stems of barley were higher in comparison with other samples, but it should be noted that in the samples with glauconite, the stems were more branched. In the zeolite samples, the stems were also quite branched, but they continued to turn yellow and dry out. In the samples with ryegrass, the stems were larger in the control samples (soil) and sometimes wider in comparison with the samples containing sorbents. However, in the zeolite and glauconite samples, ryegrass stalks were more branched compared to the control.

Thus, based on the results, it can be concluded that in the case of adding two different types of natural sorbents (zeolite and glauconite) to the substrate, there are positive changes in germination, involving the growth and development of bioindicator plants (barley and ryegrass). In addition, it should be noted that this composition of the substrate has a positive effect on the growth of ryegrass, which is an energy plant. 


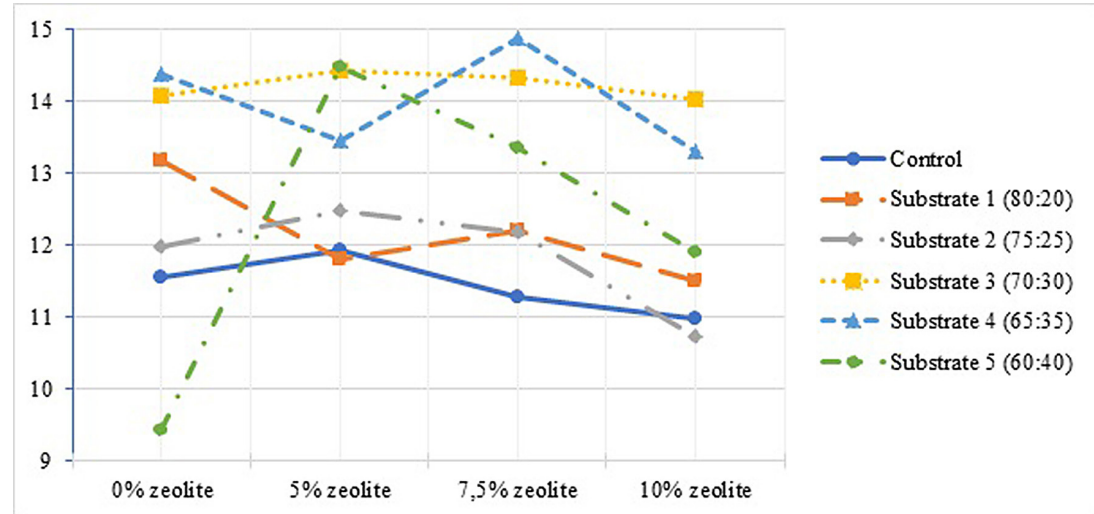

Fig. 5. Dependence of change of the growth of terrestrial plants from the substrate

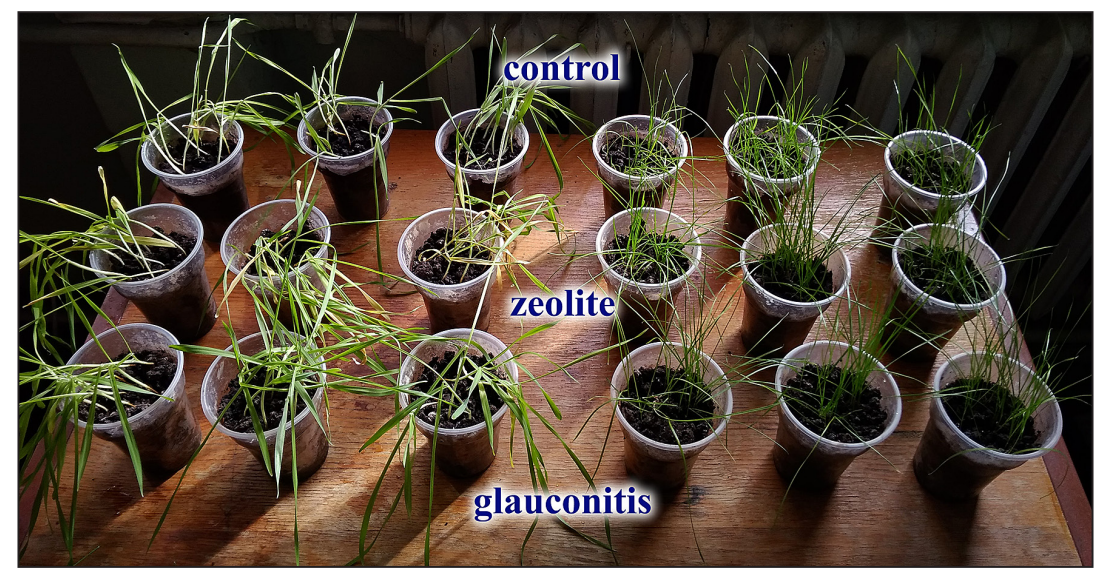

Fig. 6. General view of plants on the $40^{\text {th }}$ day

\section{CONCLUSIONS}

The content of heavy metals and nutrients in the sewage sludge accumulated on the silt field of the Lviv wastewater treatment plants was monitored. It was established that the content of test substances in sewage sludge does not exceed the maximum allowable concentrations.

According to the results of monitoring studies, it was established that the amount of mineral substance increases with the depth of occurrence in sewage sludge. The reason for this is the gravitational differentiation of the silt substrate, which is manifested in the deposition of heavier mineral components. An additional factor is their leaching from the silt by metrogenic water, followed by the movement down the section of the silt field.

The laboratory tests of bioindication of substrates based on sewage sludge, soil and natural sorbents have shown that in the case of adding an additional component (natural zeolite) to the substrate, there is a positive effect on the germination of bioindicator plants. The best germination rates were observed in the samples with a sediment content of $40 \%$ and a zeolite content of 7.5 and $10 \%$, respectively.

According to the results of phenological observations and the results of measuring the parameters of plants, the dependences of changes in growth and development of plants that can be used for biological reclamation on different types of substrate were established. It was found that in the case of using a substrate based on sewage sludge and glauconite for growing barley, the weight of one plant is $4.4 \%$ higher than in the control sample, and in the case of using a substrate based on sewage sludge and glauconite for growing ryegrass, the average stem height is $3.2 \%$ higher compared with the control sample.

It was established that the use of both natural sorbents: natural zeolite and glauconite in the substrate is optimal. The average length of ryegrass roots in the substrate with zeolite and glauconite is 5.6 and $12.3 \%$ higher, respectively, than in the control sample. 


\section{REFERENCES}

1. Chen, H., Yan, S., Ye, Z., Meng, H., \& Zhu, Y. 2012. Utilization of urban sewage sludge: Chinese perspectives. Environmental Science and Pollution Research, 19(5), 1454-1463. doi:10.1007/ s11356-012-0760-0.

2. Christodoulou, A., \& Stamatelatou, K. 2016. Overview of legislation on sewage sludge management in developed countries worldwide. Water Science and Technology, 73(3), 453-462. doi:10.2166/ wst.2015.521

3. Di Bonito, M. 2008. Sewage sludge in europe and in the UK. environmental impact and improved standards for recycling and recovery to land. Environmental geochemistry: Site characterization, data analysis and case histories (pp. 251-286) doi:10.1016/B978-0-444-53159-9.00011-5

4. DSTU ISO 11269-1: 2004 (2005). Soil quality. Determination of the effect of pollutants on soil flora. Part 1: Method for determining the inhibitory effect on root growth. Kyiv: State Standard of Ukraine, 15 p. [in Ukrainian]

5. DSTU ISO 11269-2:2002 (2004). Soil quality. Determination of the effect of pollutants on soil flora. Part 2: The effect of chemicals on the germination and growth of higher plants. Kyiv: State Standard of Ukraine, 14 p. [in Ukrainian]

6. Eurostat 2017. Sewage sludge disposal from urban wastewater treatment. Retrieved from https:// ec.europa.eu/eurostat/statistics-explained/index. php?title=File:Sewage_sludge_disposal_from_urban_wastewater_treatment,_by_type_of_treatment,_2015_(\%25_of_total_mass).png

7. Fijalkowski, K., Rorat, A., Grobelak, A., \& Kacprzak, M.J. 2017. The presence of contaminations in sewage sludge - the current situation. Journal of Environmental Management, 203, 1126-1136. doi:10.1016/j.jenvman.2017.05.068

8. Fytili, D., \& Zabaniotou, A. 2008. Utilization of sewage sludge in EU application of old and new methods - A review. Renewable and Sustainable Energy Reviews, 12(1), 116-140. doi:10.1016/j. rser.2006.05.014

9. Guedes, P., Couto, N., Ottosen, L.M., \& Ribeiro, A.B. 2014. Phosphorus recovery from sewage sludge ash through an electrodialytic process. Waste Management, 34(5), 886-892. doi:10.1016/j. wasman.2014.02.021.

10. Horova, A. \& Kulyna, S. 2008. Estimation of toxic of soils in the chervonograd mining region with the use bioindication method. Visnyk of Lviv University. Biological series, 48, 189-194. Retrieved from http://publications.lnu.edu.ua/bulletins/index.php/ biology/article/view/9215/9186 [in Ukrainian]

11. Inglezakis, V. J., Zorpas, A. A., Karagiannidis, A.,
Samaras, P., Voukkali, I., \& Sklari, S. 2014. European union legislation on sewage sludge management. Fresenius Environmental Bulletin, 23(2 A), 635-639.

12. Kacprzak, M., Neczaj, E., Fijałkowski, K., Grobelak, A., Grosser, A., Worwag, M., ... Singh, B.R. 2017. Sewage sludge disposal strategies for sustainable development. Environmental Research, 156, 39-46. doi:10.1016/j.envres.2017.03.010

13. Kievvodokanal 2018. Project "Reconstruction of Bortnytsia aeration station”. Retrieved from https:// www.vodokanal.kiev.ua/rek-bsa/ [in Ukrainian]

14. Kizyeyev, M.D., Osadchy, V.F., \& Osadchy, O.V. 2016. Investment project for the reconstruction of sewage treatment plants and the construction of a biogas production plant in Lviv. Series Theory and Building Practice, 844, 103-112. (in Ukrainian).

15. Krüger, O., Adam, C. 2015. Recovery potencial of German sewage sludge ash. Waste Management, $45,400-406$.

16. Lvivvodokanal 2018. Lviv Wastewater Biogas Project. Retrieved from http://vivvodokanal.com.ua/ aboutus/environment/sewagesludge/ [in Ukrainian]

17. Malovanyy M., Moroz O., Hnatush S., Maslovska O., Zhuk V., Petrushka I., Nykyforov V., \& Sereda A. 2019. Perspective technologies of the treatment of the wastewaters with high content of organic pollutants and ammoniacal nitrogen. Journal of Ecological Engineering, 20(2), 8-15. doi:10.12911/22998993/94917

18. Malovanyy M., Palamarchuk O., Trach I., Petruk H., Sakalova H., Soloviy Kh., Vasylinych T., Tymchuk I., \& Vronska N. 2020. Adsorption extraction of chromium ions (III) with the help of bentonite clays. Journal of Ecological Engineering, 21(7), 178-185. doi:10.12911/22998993/125545

19. Malovanyy, M., Shandrovych, V., Malovanyy, A., \& Polyuzhyn, I. 2016. Comparative analysis of the effectiveness of regulation of aeration depending on the quantitative characteristics of treated sewage water. Journal of Chemistry, 2016 doi:10.1155/2016/6874806

20. Mininni, G., Blanch, A.R., Lucena, F., \& Berselli, S. 2015. EU policy on sewage sludge utilization and perspectives on new approaches of sludge management. Environmental Science and Pollution Research, 22(10), 7361-7374. doi:10.1007/s11356-014-3132-0

21. Moroz, O.M., Hnatush, S.O., Maslovska, O.D., Yavorska, G.V., \& Borsukevych, B.M. 2020. Reduction of sulfur and oxidized forms of nitrogen by bacteria of desulfuromonas sp., isolated from yavorivske lake, under the influence of ferrum citrate. Biosystems Diversity, 28(1), 53-59. doi:10.15421/012009

22. Nebesnyi, R.V., Sydorchuk, V.V., Ivasiv, V.V., Khalameida, S.V., Orobchuk, O.M., Pavliuk, A.S., \& Tsymbalista, O.V. 2020. Effect of support nature 
on physicochemical characteristics and catalytic properties of B-P-V-W-ox oxide compositions in the condensation reaction by acetic acid with formaldehyde. Theoretical and Experimental Chemistry, doi:10.1007/s11237-020-09658-y

23. Pavšič, P., Mladenovič, A., Mauko, A., Kramar, S., Dolenec, M., Vončina, E., ... Bukovec, P. 2014. Sewage sludge/biomass ash based products for sustainable construction. Journal of Cleaner Production, 67, 117-124. doi:10.1016/j.jclepro.2013.12.034.

24. Petruk, V., Vasylkivskyi, I., Bezvoziuk, I., Petruk, R., \& Turchyk, P. 2013. Environmental technologies. Part three. Methods of sewage sludge treatment. 324 p. Retrieved from http://vasilkivskiy. vk.vntu.edu.ua/file/86d4ec3ed547e516d3223cc00 edbbc39.pdf [in Ukrainian]

25. Shchur, I., \& Biletskyi, Y. 2019. Passivity-based control of hybrid energy storage system with common battery and modular multilever DC-DC converterbased supercapacitor packs. Paper presented at the 2019 IEEE 20th International Conference on Computational Problems of Electrical Engineering, CPEE 2019, doi:10.1109/CPEE47179.2019.8949174

26. Twardowska, I., Schramm, K.-W., \& Berg, K. 2004. Sewage sludge. Waste Management Series (pp.239295) doi:10.1016/s0713-2743(04)80013-8.
27. Tyagi, V. K., \& Lo, S.-L. 2013. Sludge: A waste or renewable source for energy and resources recovery? Renewable and Sustainable Energy Reviews, 25, 708-728. doi:10.1016/j.rser.2013.05.029

28. Tymchuk, I., Shkvirko, O., Sakalova, H., Malovanyy, M., Dabizhuk, T., Shevchuk, O., Matviichuk O., Vasylinych, T. 2020. Wastewater a source of nutrients for crops growth and development. Journal of Ecological Engineering, 21(5), 88-96. doi:10.12911/22998993/122188

29. Werle, S. 2015. Sewage sludge-to-energy management in eastern europe: A polish perspective. Ecological Chemistry and Engineering S, 22(3), 459-469. doi:10.1515/eces-2015-0027.

30. Xu, C., Chen, W., \& Hong, J. 2014. Life-cycle environmental and economic assessment of sewage sludge treatment in china. Journal of Cleaner Production, 67, 79-87. doi:10.1016/j.jclepro.2013.12.002

31. Yang, G., Zhang, G., \& Wang, H. 2015. Current state of sludge production, management, treatment and disposal in china. Water Research, 78, 60-73. doi:10.1016/j.watres.2015.04.002.

32. Zelenko, Y., Malovanyy, M., \& Tarasova, L. 2019. Optimization of heat-and-power plants water purification. Chemistry and Chemical Technology, 13(2), 218-223. doi:10.23939/chcht13.02.218 